ENVIRONMENTAL SCIENCE

\title{
Water Scarcity- Challenging the Future
}

\section{Niruban Chakkaravarthy* and T. Balakrishnan}

Department of Agricultural Extension, Faculty of Agriculture, Annamalai University, Tamil Nadu, India

*Corresponding author: chakkarainiruagri95@gmail.com (ORCID ID: 0000-0001-8382-2920)

Paper No. 783

Received: 09-05-2019

Revised: 06-07-2019

Accepted: 21-08-2019

\begin{abstract}
The latest world water development reports (UN-Water, 2009) observe how the various global crisis reported recently- in climate change, energy, food security, economic recession and financial turbulenceare related to each other and have impacts on water. Water Scarcity is a growing threat to our global economy, society and even to the survival of human beings. The crisis that we face today is mainly due to water pollution especially in the field of agriculture. Pollution can be anything from oil, to carcasses, to chemicals and to fecal matter, whatever the cause it majorly affects the global population. The world is moving towards a direction where water is becoming costly hence not affordable by the majority of people. As far as India is concerned it is gifted with many water bodies but due to improper management and unscientific industrial development. We are staring at the increase in the death of rivers. Erratic development plans mean our future generation is in major threat, sustainable development plans mean our future generation is saved from such major threat, sustainable development is the hour of need. Apart from government policies, the change needs to come from the grass-root level. This paper deals with water use and savings for the future. It also highlights the importance and threats of water scarcity and the challenges that will be faced by future generations.
\end{abstract}

\section{Highlights \\ (0 Erratic development goals have endangered the future generation. \\ 0 Threats of water scarcity and its challenges.}

Keywords: Global population, Food security, Pollution, Sustainability, Water scarcity

Water is life because plants, animals, human beings and any other living organisms cannot live without water. Water is needed to ensure food security, feed livestock, and take up industrial production and to conserve the biodiversity and environment. The fresh water is the only available sources for all activities such as drinking, industries agricultural all other purposes. Although India is not a water-poor country, due to the growing human population, severe neglect and over-exploitation of this resource, water is becoming a scarce commodity. While this is a growing concern all over the world, India is most vulnerable because of the growing demand and in-disciplined lifestyle. This calls for immediate attention by the stakeholders to make sustainable use of the available water resources to ensure a better quality of lives. By 2025, one-third of the population of the developing world will face severe water shortages (Seckler et al. 1998). Yet, even in many water-scarce regions, large amounts of water annually flood out to the sea. However, in many cases, the floodwater is not fully utilized; and, of course, the floods themselves can do a great deal of harm. More than two billion people worldwide live in regions facing water scarcity and in India, this is a particularly acute crisis. Millions of Indians currently lack access to clean drinking water, and the situation is only getting worse. India's demand for water is growing at an alarming rate. India currently has the world's second-largest population, which is expected to overtake China's by 2050 when it reaches a staggering 1.6 billion, putting increasing strain on water resources as the number of people grows. Since the balance between water demand 
and water availability has reached critical levels in many countries of the world and increased demand for water and every sector production is the biggest challenge in the future, a sustainable approach to water resource management in every sector is very essential. In this circumstance, the focus of this article is to provide a vision review of water scarcity causes and how it's the affected our world society and what are the possible ways to overcome this problem, these things are briefly discussed.

\section{Water Scarcity and Types}

"When an individual does not have access to safe and affordable water to satisfy her or his needs for drinking, washing or their livelihoods we call that person water insecure". Hence, when a large number of people in an area are water insecure for a considerable period of time, in that case, we can name that area water scarce (Rijsberman 2006:6). It was divided into two types which were physical and economic water scarcity (The project water). Physical scarcity means some area lack of water is a more profound problem. Physical access to water is limited that demand outstrips the lands ability to provide the needed water and it's Happen in the dry part of the world or arid region (UNDP 2006). Economic scarcity is by far the most disturbing form of water scarcity because it is almost entirely a lack of consideration and good governance that allows the condition to continue. Economic water scarcity is about an unequal distribution of resources for many reasons, including political and ethnic contradiction.

\section{Reasons for Water Scarcity}

Water scarcity is one of the greatest challenges of the twenty-first century. Overpopulation, Agriculture, Pollution of water and improper government policies are the important reasons for water scarcity. FAO reported agriculture, encompassing crops, livestock, fisheries, aquaculture, and forestry, is both a cause and a victim of water scarcity. It accounts for an estimated 70 percent of global water withdrawals, while competition with other sectors for water is increasing.

Climate change also affects freshwater resources negatively, in terms of both quantity and quality. Particularly the demand for water in India is steeply increasing because of several reasons, such as urbanisation, Industrialisation, more water for agriculture production and vigorous population growth (Amarasinghe et al. 2007).

\section{Population growth}

The world's population is growing at a rate of 80 million people each year. This means that each year we need to find a way to add about 64 billion cubic meters of water to the global water supply India is the second-most populous country in the world, with more than 1 billion citizens. Roughly half of India's population, a staggering 569 million, practice open defecation. In the year 2030, India will be number one in population. There are millions of people all over the world who don't have access to water, or, if they have access, that water is unable to be used. About 70\% of the Earth's surface is covered with water and 3\% of it is actually freshwater that is fit for human consumption. According to WWF (world wildlife fund), some 1.1 billion people worldwide lack access to water, and a total of 2.7 billion find water scarce for at least one month of the year.

\section{Pollution of water}

Water pollution is a huge problem, especially when you're looking at areas that don't necessarily have a good sewage system. Pollution can be anything from oil, to carcasses, to chemicals, and to fecal matter. Water pollution affects the entire biosphere plants and organisms living in these bodies of water. Water pollution is a major global problem which requires ongoing evaluation and revision of water resource policy at all levels. In view of population increase, the demand for freshwater for all the uses will be unmanageable. According to the status of water quality in India (2011), it is estimated that the projected wastewater from urban centres may cross 1,00,000 mld (millions of litter per day) by 2050 and rural India will also generate not less than 50,000 mld in view of water supply designs for community supplies in rural areas.

\section{Agriculture use}

Ninety percent of total water resources used in agriculture. Eighty percent of groundwater goes to irrigation and agricultural purposes. While agriculture is one of our countries most significant water users some innovative solutions have been developed to improve water use efficiency and 
maintain or even increase yields. In below fig explained how water was used by agriculture in various formats. In the future, the demand for food is highly expected, with a direct effect on agricultural water usage. In addition, as a result of the increased water scarcity and drought due to climate change (Jiménez Cisneros et al. 2014), extensive water use for irrigation is expected to occur in the context of increasing competition between agriculture and other sectors of the economy. In order to cope with future estimates of water shortages, some measures aimed at streamlining and optimizing the efficiency of water consumption in the agricultural sector are critical in view of the large volumes of water required for the production of crops. Irrigation is used to replace losses due to crop evapotranspiration and to achieve full production under the given growing environment (Doorenbos, 1977).

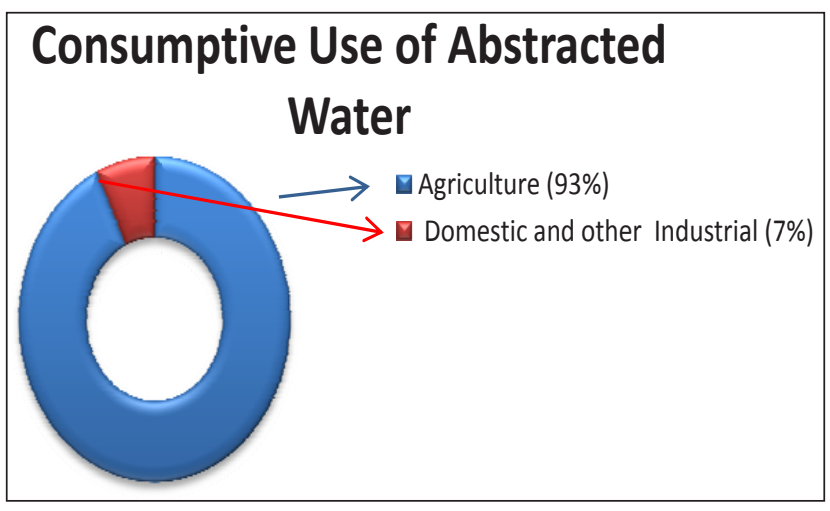

Fig. 1

Source: Word bank-Word bank-Wold Development Report-2010.

\section{Government policies}

In some countries, specifically those with dictatorships, the use of water may be strictly controlled by those in power, causing a scarcity for those who may be located in those areas of the world. These governments use it as a source of control over those that they are governing, which can be a huge problem. Proper policies are making by government and strict the rules which are the ways to reduce the water scarcity. Government policies are playing a major role in reducing the water scarcity problems and the government should initiate the water-related activities such as project, awareness programmes to know the importance of water conservation so the country able is to avoid over-exploitation of water.

\section{Effects of water scarcity}

There is a growing body of research that asserts again strongly the importance of water in regards to geopolitical stability. Human health and agricultural concerns are also of great importance. Leaders use to access to water as a political tool or as a way to consolidate political power. It creates various effects on the livelihoods of millions of farmers and highly affects the ecosystem of a country.

\section{Lack of drinking water}

The availability of total freshwater resources in the world are estimated to be in the order of 43,750 $\mathrm{km}^{3}$ year ${ }^{-1}$, distributed throughout the world; at the continental level, America has the largest share of the world's total freshwater resources, with $45 \%$, followed by Asia with $28 \%$, Europe with $16 \%$, and Africa with $9 \%$. In terms of resources per inhabitant in each continent, America has 24,000 $\mathrm{m}^{3}$ year $^{-1}$, Europe $9300 \mathrm{~m}^{3}$ year $^{-1}$, Africa $5000 \mathrm{~m}^{3}$ year $^{-1}$ and Asia $3400 \mathrm{~m}^{3}$ year $^{-1}$. Clean drinking water is scarce and there are millions of people and other organisms across this globe who spend their entire day searching for it. Yet, people who have access to safe, clean drinking water take it for granted and don't use it wisely. Water scarcity involves water crisis, water shortage, water deficit or water stress. The biggest problem that happens when you have water scarcity is that people are not able to get fresh, clean drinking water.

\section{Hunger}

Non-availability of water leads to low production which ends in hunger and poverty. Animals will also die, which will result in a lack of meat as well. Water scarcity, in short, causes starvation to occur as a group for both people and animals that are located in the area.

\section{Lack of Education}

Water scarcity makes it difficult for people to get the education that they need or that they deserve. Why? Mainly, because those children are either too sick to go to school or they are working to help get water to the home and the family. Cairncross et al. (1987) highlighted that villagers in a study community without a close water supply stated that they often "cooked little, and only once a day, 


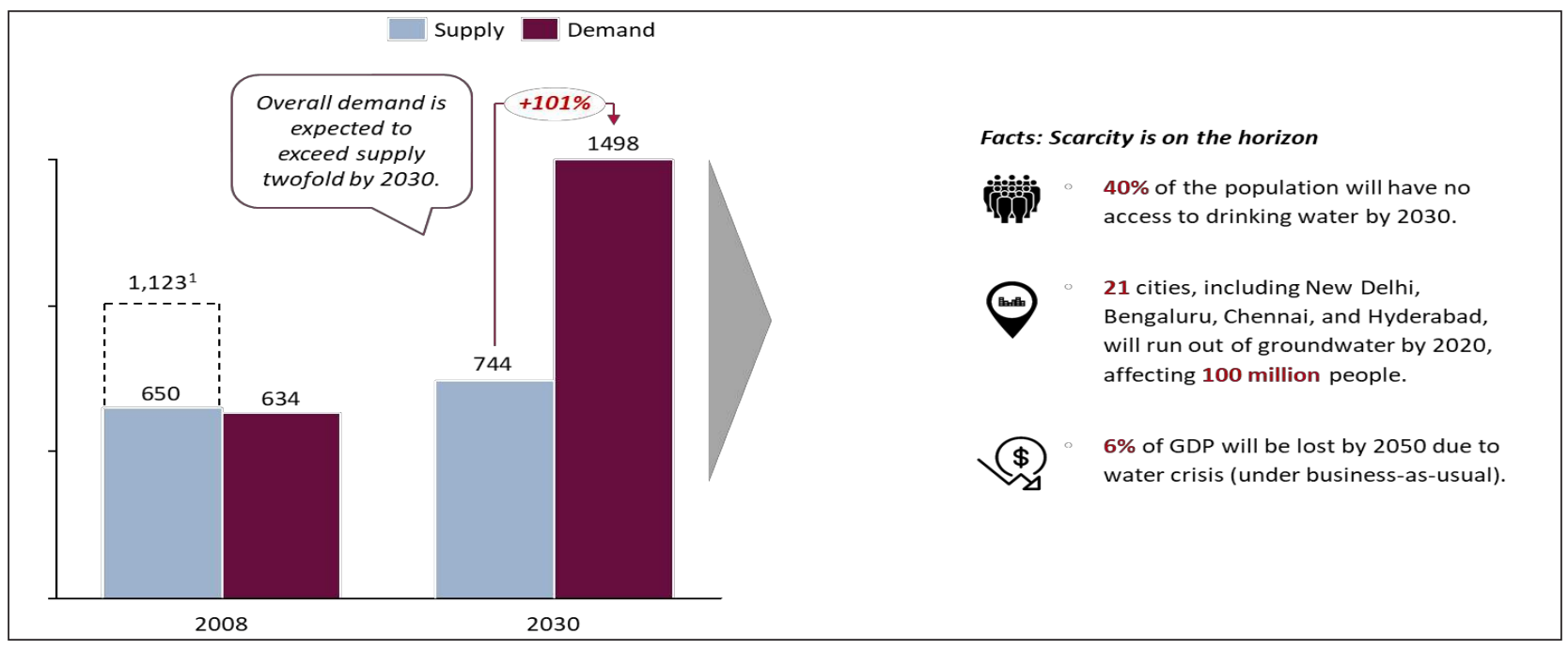

Fig. 2: Demand and supply of water in India (forecast) In BCM (2008, 2030)

Notes: 1. Water supply for 2008 is Narsimhan's estimate of 650, while the planning commission estimate is 1,123, as represented by the dashed by the portion of the graph; 2. Demand for 2008 is based on the planning commission's estimates; 3 . Supply and demand for 2030 are projections by McKinsey and Water Resources Group (WRG).

Sources: Dalberg analysis; CWC Water \& Related Statistics 2013; FAO E UNICEF, Water in India 2013; McKinsey E WRG, 'Charting our water future', 2009; World Bank' Times of India.

because of the lack of water". In the same study, the findings provide a detail that the community with better water access had a prevalence of trachoma of $19 \%$ versus $38 \%$ in the community without ready access to water. The authors concluded that hygiene practices and hygiene-related health outcomes appeared directly related to how far the water source is from a household. Time spent collecting water has also been found to be associated with significant "coping costs and the people have a no time to study and they are able to concentration which automatically leads to lack of education and poverty. This is a mournful problem, affected by most of the countries and lack of water is ultimately aims to lack of equity. Especially in girls, due this problem their status is highly suffered.

\section{Sanitation and other Issues}

The World Bank has identified hygiene promotion as the most cost-effective of all interventions to control high-burden diseases in the developing world, with sanitation promotion close behind (Laxminarayan, Chow and Shahid-Salles 2006). The direct health consequences of poor hygiene and sanitation are generally well known. It is estimated that nearly 5000 children die every day from the effects of diarrhoeal illnesses, 90 per cent of which are attributable to poor hygiene, sanitation and unsafe water (UNICEF 2006). In countries with high infant mortality rates, the lack of access to clean water and sanitation kills more children than pneumonia, malaria, and HIV and AIDS combined. Half of the world's hospital beds are engrossed by people distressing from waterborne diseases. Hygiene and sanitation also help to control many non-fatal diseases which afflict young children, such as intestinal parasites, blinding trachoma, and impetigo. Finally, improved hygiene and sanitation have important positive impacts on the quality of life enjoyed by children, including the benefit of being part of a household with a greater chance of escaping poverty. The quality of life of the people is affected because of water scarcity. One in nine humans on Earth suffers from chronic thirst and diseases caused by drinking polluted water (WHO, 2014). $82 \%$ of those who lack access to improved water live in rural areas, while just $18 \%$ live in urban areas (WHO, 2014). In all 2.6 billion people live in inadequate sanitary conditions (UNHDR, 2006). Most problems are concentrated in Africa and Asia - this is where most people afflicted by thirst, malnutrition and associated illnesses live.

Poor access to water and sanitation also has important knock-on effects in terms of the attainment of educational goals, particularly for girls (DFID 2007). Girls stay away from school because it is seen 


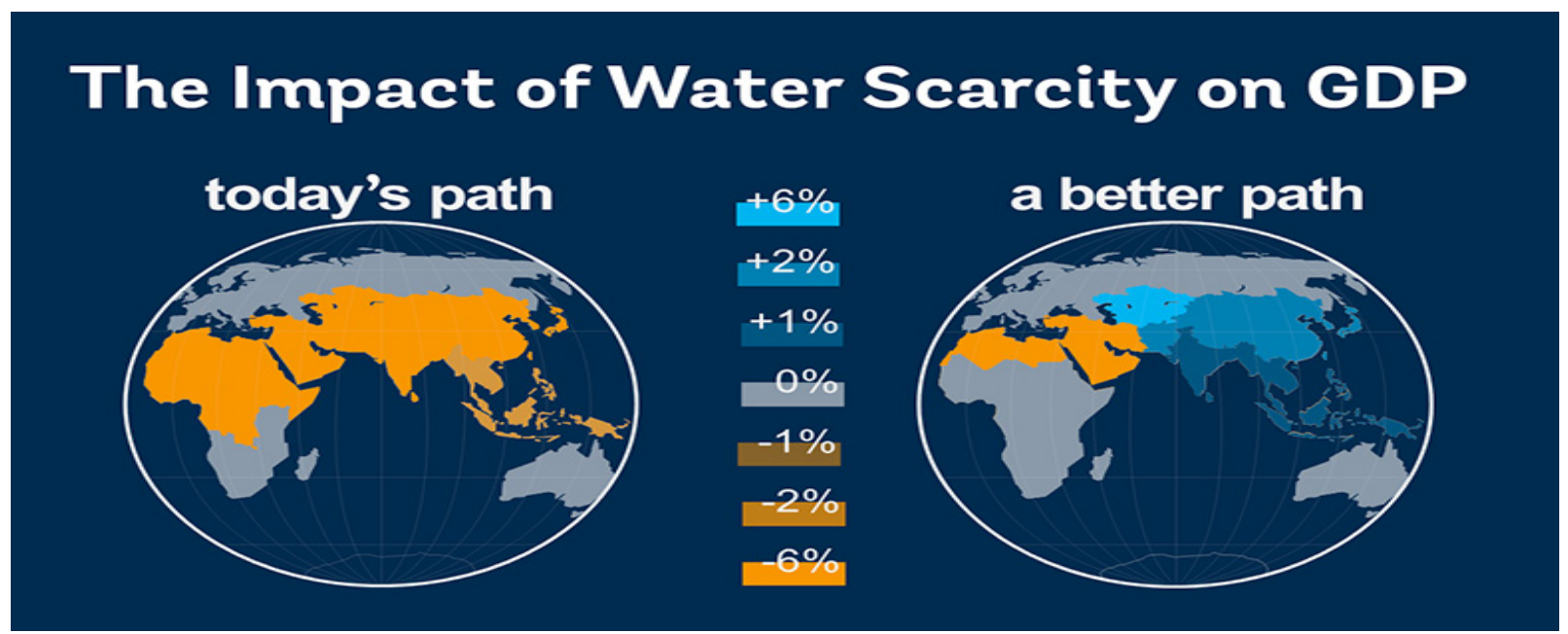

Fig. 3

as their job to bring in water. Also, they are kept away from school for want of sanitation facilities when menstruating. Intestinal worms, spread by poor sanitation, also inhibit cognitive development, and illnesses due to poor hygiene and sanitation prevent children from attending school. The United Nations Children's Fund (UNICEF 1999) found that improved school sanitation boosted girls' school attendance by 11 per cent in Bangladesh - a degree of impact that is likely to be as significant as major educational reform. A Water Aid Tanzania (2002) study found that school attendance rose by 12 per cent when safe water was made available fifteen minutes rather than one hour away from children's homes. Additionally, children queuing for inadequate communal toilets at school or near home miss out on classwork or homework. And, in some instances, teachers have been found to resist being posted to communities which lack adequate sanitation. Without access to clean water, there is no way to clean food, dishes, or people. When people are not given access to proper sanitation, disease ends up becoming much more of an issue than it would have been otherwise. It also causes mental health issues, including depression and anxiety.

\section{Poverty}

All in all, people who are dealing with water scarcity are often stuck in poverty as well. Most of the countries are now a day suffered this issue. Water is the biggest resource to enhance the growth and economy of every nation. Water scarcity sees it as a symptom of poverty.
Not having adequate water or sanitation is thus, seen as a characteristic of less developed countries. The World Bank (1992: 11) and Shafik (1994), report negative relationships between per capita GDP and percentage of the population not having access to water supply and sewerage.

\section{Reducing the Water Scarcity}

The water supply in India is going to be a serious challenge due to various reasons. The most serious concern is the growing population which is likely to increase to 1.66 billion by 2050 . With the increasing population, the annual food requirement in the country will exceed 250 million tons. Increasing the water storage capacity has been one of the ways to mitigate water scarcity. Rain water harvesting is one of the key features to overcome this problem. Multiplied the farm ponds, percolation tanks, water reservoirs and construction of small and mediumsize dams and rivers can ensure the ground water as well as surface water. The prime important elucidation is to entwine of rivers will help in forestall floods while enhancing water distribution in the country and reforestation of degraded forests and development of wastelands through afforestation will help in soil and water conservation (IDSA, 2010).

\section{National Water Policy}

India had revised the NWP in 2002 with the following salient features (Government of India, 2009. Establishment of National and State level data banks to monitor the demand and supply. 
These are some key points for facilitation for the transformation of available water resources into utilizable water and non-conventional methods for efficient water use. Supply of water from water surplus areas to water shortage areas. Judicious allocation of water for different uses and pricing of water is to ensure sustainable development. Regulation on groundwater exploitation and close monitoring of water table using modern scientific techniques Sustainability of existing water bodies, involving all the stakeholders and local communities. The master plan for flood control is which mean linking different rivers and promoting soil conservation measures. Reduces strain on Special Village Panchayats/ Municipal / Municipal Corporation water supply.

\section{Agriculture Sector}

More food less water is a very important focus approach of current situation in agriculture. In the agricultural sector, one of the important components is an improvement in water usage efficiency and adoption of rainwater harvesting and watershed management techniques. Another aspect in the agricultural sector reduction of subsidies on power supply particularly for pumping water which leads to prevention of groundwater exploitation by introducing differential pricing, rewards, and punishments. Implementation of National River Link project which aims to connect 30 rivers and canals to generates 175 trillion litres of water.

\section{Industrial Sector}

The industrial sector is one Encourage recycling and treatment of industrial wastewater through regulations and subsidies. Encourage the introduction of new technologies which consume less water.

\section{Domestic Sector}

In the domestic sector, Introduction of a policy for mandatory rainwater harvesting in cities and Propagation of efficient water usage and creation of awareness about water conservation among the common public which is strengthening the water policy.

\section{Augmentation of Water Resources}

While the consumption of water in India will increase by over $50 \%$, the supply will increase only by $5-10 \%$ during the next $12-15$ years. This will lead to water scarcity situation and most of the people, particularly those who are dependent on agriculture and living in poverty will suffer the most.

Finally, increasing the water storage capacity, efficient irrigation practices, watershed development, control of water pollution, desalination of sea water, research and development for respected areas of effective way for reducing the water scarcity. Rainwater harvesting is the most important muchneeded practice in the current situation. It is a technique of collection and storage of rainwater into natural reservoirs or tanks, or the infiltration of surface water into subsurface aquifers (before it is lost as surface runoff). It is the perfect time for reconstruct the policy and preventing the war because of water scarcity.

\section{CONCLUSION}

This paper attempted to investigate and discuss the details about water scarcity and its problem and how to overcome this problem because the world, as well as India, has an alarming situation due to this problem. In World, in some of places of worlds are announced by unfit place for living any organism. So, within this concern this paper highlights the alarming situation of water scarcity, particularly the developing sector like industries, agriculture productions go down due to water shortage. It will create a huge impact on country's economy. Sustainable action and strong polices are emergently needed to overcome this situation. So only we will able to save our future.

In this current scenario, appropriate action is needed to prevent this crisis by making best use of innovative technologies and resources to conserve the remaining water sources. Agriculture, industry and domestic are the major sectors consumed more quantity of available water. So, the regulatory bodies such as governments and organisations are forming the strong regulatory measures should prevent the misuse of water and introducing rewards and punishment to encourage judicious use of water, will be helpful to conserve water. Finally, create awareness and conduct the various programmes can able to understand the real situation of water scarcity, So, the people are able to manage the situation and change their lifestyle. 


\section{REFERENCES}

United nations, report for global issues on water n.d., assessed on 19 June 2016, http://www.un.org/en/sections/issuesdepth/water

The water project, Water Crisis -India n.d., assessed on 10 May 2018, https://thewaterproject.org http://mowr.gov.in

United Nations Development Programme. 2006. Human Development Report 2006: Beyond Scarcity-Power, Poverty and the Global Water Crisis. Basingstoke, United Kingdom:Palgrave Macmillan.

Rijsberman, F.R. 2006. 'Water scarcity: Fact or fiction?' Agricultural Water Management Journal, 80: 5-22.

Seckler, David, David Molden and Randolph Barker. 1998. Water scarcity in the twenty-first century. IWMI Water Brief 1. Colombo, Sri Lanka: International Water Management Institute.

CWC, 'Water \& Related Statistics'. 2013. FAO \& UNICEF, Water in India, 2013; McKinsey \& WRG, 'Charting our water future', 2009; World Bank; Times of India.

World Bank. 1992. World Development Report 1992: Development and the Environment, Oxford University Press, New York.

Shafik, N. 1994. Economic Development and Environmental Quality: An Econometric Analysis. Oxford Economic Papers, 46: 757-773.

Amarasinghe, U.A., Shah, T., Turral, H. and Anand, B.K. 2007. India's water future to 2025-2050: Business as usual scenario and deviations. Research Report 123, IWMI. pp. 52.

IDSA. 2010. Water Security for India: External dynamics. IDSA Task Force Report.

Govt. of India. 2009. Background note for consultation meeting with Policy makers on review of National Water Policy. Ministry of Water Resources, pp. 50.

Cairncross, S. and Cliff, J.L. 1987. Water use and health in Mueda, Mozambique. Trans. R. Soc. Trop. Med. Hyg., 81: 51-54.

Laxminarayan, R., Chow, J. and Shahid-Salles, S.A. 2006. Intervention cost-effectiveness: overview of main messages. In Disease control priorities in developing countries. New York: Oxford University Press.
DFID Sanitation Reference Group. 2007. Water is life, sanitation is dignity. Sanitation Policy Background Paper. London: Department for International Development. www.dfid. gov.uk/consultations/past-consultations/ water-sanitation-background.pdf

UNICEF. 1999. Sanitation and hygiene: A right for every child. New York.

Water Aid. 2002. Water and sanitation in Tanzania: Poverty monitoring for the sector using HBS, the DHS and the population censuses. Water Aid Tanzania with Eastern Africa Statistical Training Centre and National Bureau of Statistics. Dar es Salaam: Water Aid Tanzania. www. wateraid.org/documents/population_census_study.pdf.

UNICEF. 2006. Children and water, sanitation and hygiene: The evidence. Issue note for the UNDP 2006 Human Development Report. New York.

Jiménez Cisneros, B.E., Oki, T., Arnell, N.W., Benito, G., Cogley, J.G., Döll, P., Jiang, T. and Mwakalila, S.S. 2014. Freshwater resources. In Climate Change; Impacts, Adaptation, and Vulnerability. Part A: Global and Sectoral Aspects. Contribution of Working Group II to the Fifth Assessment Report of the Intergovernmental Panel on Climate Change. Eds.; Cambridge University Press: Cambridge, UK and New York, NY, USA, pp. 229-269.

Doorenbos, J. and Pruitt, W.O. 1977. Crop water requirements. In FAO Irrigation and Drainage Paper 24, $2^{\text {nd }}$ ed.; FAO: Rome, Italy.

Food and Agriculture Organization of the United Nations. 2003. Review of World Water Resources by Country; Water Report No. 23; FAO: Rome, Italy.

WHO. 2014. World Health Organization and UNICEF Joint Monitoring Programme (JMP), Progress on Drinking Water and Sanitation, 2014 Update.

UNHDR. 2006. United Nations Human Development Report, pp. 6, 7, 35 http://www.undp.org/content/dam/undp/ library/corporate/ HDR/2006\%20Global\%20HDR/HDR2006-Beyond\%20scarcityPower-poverty-and-the-globalwater-crisis.pdf (accessed 01.07.2015) 
